\title{
Environment, Resources and Interpretation: Influences in the Internationalization Strategies of the Food Industry in Brazil
}

Rene E. Seifert Jr.

E-mail address : r.e.seifert@gmail.com

CEPPAD/UFPR

Curitiba, PR, Brazil

Clóvis L. Machado-da-Silva*

E-mail address: clms@terra.com.br

UnicenP and CEPPAD/UFPR

Curitiba, PR, Brazil

\begin{abstract}
This article analyzes the internationalization strategies of companies in the food industry from Paraná State, in Brazil. The logic of analysis sought to corroborate the idea that internationalization is a strategic phenomenon cognitively mediated in the light of environmental pressures and resources within the organization. Therefore, the role of the environment, resources and interpretive schemes are analyzed and used to explain three strategic internationalization patterns found in the food industry of Paraná: domestic, reluctant and active international action. Based on those constructs, and from an institutional and cognitive perspective of analysis, the study contributes to the debate related to homogeneity, heterogeneity and organizational strategic action.
\end{abstract}

Key words: internationalization; environment; resources; interpretation; institutional theory.

Received 18 October 2004; received in revised form 20 May 2005.

Copyright (C) 2007 Brazilian Administration Review. All rights reserved, including rights for translation. Parts of this work may be quoted without prior knowledge on the condition that the source is identified.

*Corresponding author: Clóvis L. Machado-da-Silva

Av. Visconde de Guarapuava, 4487, apto. 4, Edifício Paul Cézanne, Batel, 80240-010, Curitiba, PR, Brazil. 


\section{INTRODUCTION}

The internationalization process has became a growing phenomenon in last decades. However, despite its increased importance, it appears to be far from being completely understood. As Axinn and Matthyssens $(2001,2002)$ observed, firms are internationalizing faster, in different ways, using different combinations of entry mode, at the same time that the world changes more rapidly. In that way, they argued that available theories are inadequate to account for internationalization. As we see it, although internationalization is a complex and dynamic phenomenon, perhaps impossible to be completely understood by one single theoretical analytical approach, it constitutes a fertile and interesting ground of empirical investigation.

Historically, internationalization studies have been dominated by two main theoretical streams: theories of economic approach and theories of behavioral approach (Andersson, 2000; Jones \& Coviello, 2005). Whereas both approaches shed some light on internationalization, there are still several limitations and gaps of knowledge involving this phenomenon. For example, economic and behavioral theories of internationalization fail to incorporate historical and institutional aspects that influence internationalization and international business. Additionally, in more recent years, despite the growing debate regarded to the role of resources on internationalization, little is known about the specific resources on which international expansion is based (Tallman, 2001; Hitt, Bierman, Uhlenbruck, \& Shimizu, 2006). Furthermore little is also known about the role of cognitive mechanisms in internationalization (Zahra, Korri, \& Yu, 2005).

In this study, we argue that internationalization is a strategic phenomenon, cognitively processed by organizational members and susceptible to the influences of environmental pressures and resources. Within this understanding, we carried out a study focusing on the role of environment, resources and interpretive schemes in the internationalization process of the Paraná food industry in Brazil. On doing so, we have adopted a theoretical analytic model of internationalization proposed by Machado-daSilva and Seifert Jr. (2004) that integrates internal, external and cognitive influences on that process. The results demonstrate how Brazilian environmental changes influenced the internationalization process of firms in the Paraná food industry; present evidence concerning critical resources within that process; and shed light on how organizational members cognitively define environmental domains of action and from there apprehend values and meanings that guide their strategic choices related to the internationalization process.

\section{THEORETICAL FRAME OF REFERENCE}

Despite its generic understanding, internationalization has usually been linked to the idea of the involvement of firms in international operations (Welch \& Loustarinen, 1988). As an academic field of inquiry, it grasps a phenomenon that became mainly recurrent after the Second World War and which since the 1960s has received growing academic attention (Parker, 1998). In that way Hymer's (1976) $\mathrm{PhD}$ thesis has been traditionally pointed to as the main systematic effort on understanding why organizations become engaged in international operations and what could explain this course of action. Since Hymer (1976) several theories have been presented. Nowadays authors tend to agree that two streams of research were established: one based on economic and the other on behavioral assumptions of social action (Johanson \& Vahlne, 1990; Andersson, 2000; Jones \& Coviello, 2005).

Since its pioneer studies in the 1960s the economic perspective has offered somehow different but complementary explanations of international operations. Hymer (1976) linked foreign direct investment with the possession of monopolistic advantages. Vernon (1966) argued about the relationship between the product life cycle and international investment and trade. In the late 1970s, Buckley and Casson (1976), Rugman (1980) and Hennart (1982) based on transaction cost assumptions (Coase, 1937; Williamson, 1975) called for a theory of multinational operations. Their 
assumption is that firms choose their international operation mode (whether market or hierarchy), structure and location based on assessment and minimization of the economic costs involved in international transactions. In the 1980s, Dunning $(1980,1988)$ proposed an economic eclectic view of international operations based on ownership, location and internalization advantages. In this way did he combine the main economic theoretical approaches developed so far. Dunning's eclectic paradigm argues that firms will only invest directly in a foreign market when three distinct sets of advantages are present (ownership-specific advantages, internalization advantages and location advantages).

On the other hand, the behavioral approach of internationalization emerged as a separate research stream from economics and was influenced by the works of Cyert and March (1963) and Aharoni (1966). The approach argues that internationalization is a sequence of steps by which companies acquire experience and knowledge about external markets through the gradual commitment of resources and learning by doing. The perspective assumes that current knowledge and commitment to the market affect the decisions made concerning the commitment of resources in overseas markets in the next step (Johanson \& Vahlne, 1990). According to Johanson and Vahlne (1990) the process model of internationalization can account for two patterns of internationalization in companies. The first is that the engagement of the company in a specific external market happens in stages. The second is that companies access new markets, successively increasing their psychic distance.

Whereas both perspectives are sources of substantial explanatory knowledge of internationalization, not all questions pertaining to the phenomenon are answered (Andersson, 2000). Economic theories still maintain strong links with absolute rationality, profit maximization and optimization. They assume economic man is able to access all information needed and rationally chooses the best solution. However, it does not recognize that those with the power to decide within organizations can take different decisions based on their interpretations. Furthermore, economic theories do not explain why organizations do not internationalize when there would be economic advantages in doing so (Andreff, 2000) or, likewise, why some organizations internationalize even when they have not all the necessary set of advantages to do it. On the other hand, behavioral theories, in spite of recognizing the limits of rationality and the need to learn about internationalization, have been criticized for their determinism (Reid, 1981; Turnbull, 1987; Melin, 1992). Therefore, if internationalization develops according to behavioral propositions, managers are deprived of their ability to make strategic choices (Andersson, 2000). Additionally behavioral theories do not take into account that the internationalization process of numerous new firms has not developed in stages and has otherwise captured distant markets in terms of psychic distance (Turnbull, 1987; Oviatt \& Mcdougall, 1994, 1995). Furthermore, some authors have criticized sequential models of internationalization since several firms develop to a determined stage and do not evolve to the other stages of internationalization (Reid, 1981).

Despite the theoretical limitations of economic and behavioral theories of internationalization, it seems important to recognize that both approaches call attention to the fact that internationalization can be influenced by both external and internal variables. As external variables, economic theories point to the role of: location advantages, comparative advantages, industry characteristics, uncertainty, government intervention and opportunism, among others. At the same time, behavioral theories focus on the psychic distance, geographic distance, cultural differences, inter-organizational networks, and so on. On the other hand, focusing on internal variables, economic theories emphasize the role of ownership advantages, tacit knowledge, product characteristics, communication ability, among others, while the behavioral theories point to the relevance of experiential knowledge and learning.

External variables that influence internationalization point to the role of the environmental context in which the organization is embedded. In the same way, internal variables like ownership advantages, abilities, product characteristics, size and knowledge, among others, can in broad terms be regarded as resources available for internationalization. In that understanding, we assume that internationalization is influenced both by the environmental context as well by the resources available or not within the organization. Although it is evident that many studies have inquired as to the influences of internal and external aspects on internationalization, rarely have they done it in an integrative way. Usually they are studied separately. Additionally, and probably more important is the fact that studies tend to ignore 
that both internal and external aspects that influence internationalization, here named environment and resources, are susceptible to interpretation by the managers. In this light, Bell, Mcnaughton, Young and Crick (2003) in his integrative model of internationalization called attention to this point. What we have in mind is the fact that internationalization, as a strategic process, implies the cognitive mediation or interpretation by those who primarily are responsible for the strategic decisions related to internationalization issues. At this point we point to the role of the interpretive schemes within organizations and their cognitive mediation between the pressures of the environmental context and organizational resources.

From the previous discussion we are able to have a better look at the analytical model proposed by Machado-da-Silva and Seifert Jr. (2004) that underpins this study. The model is presented in Figure 1.

Figure 1: Analytic Model of Internationalization Strategies

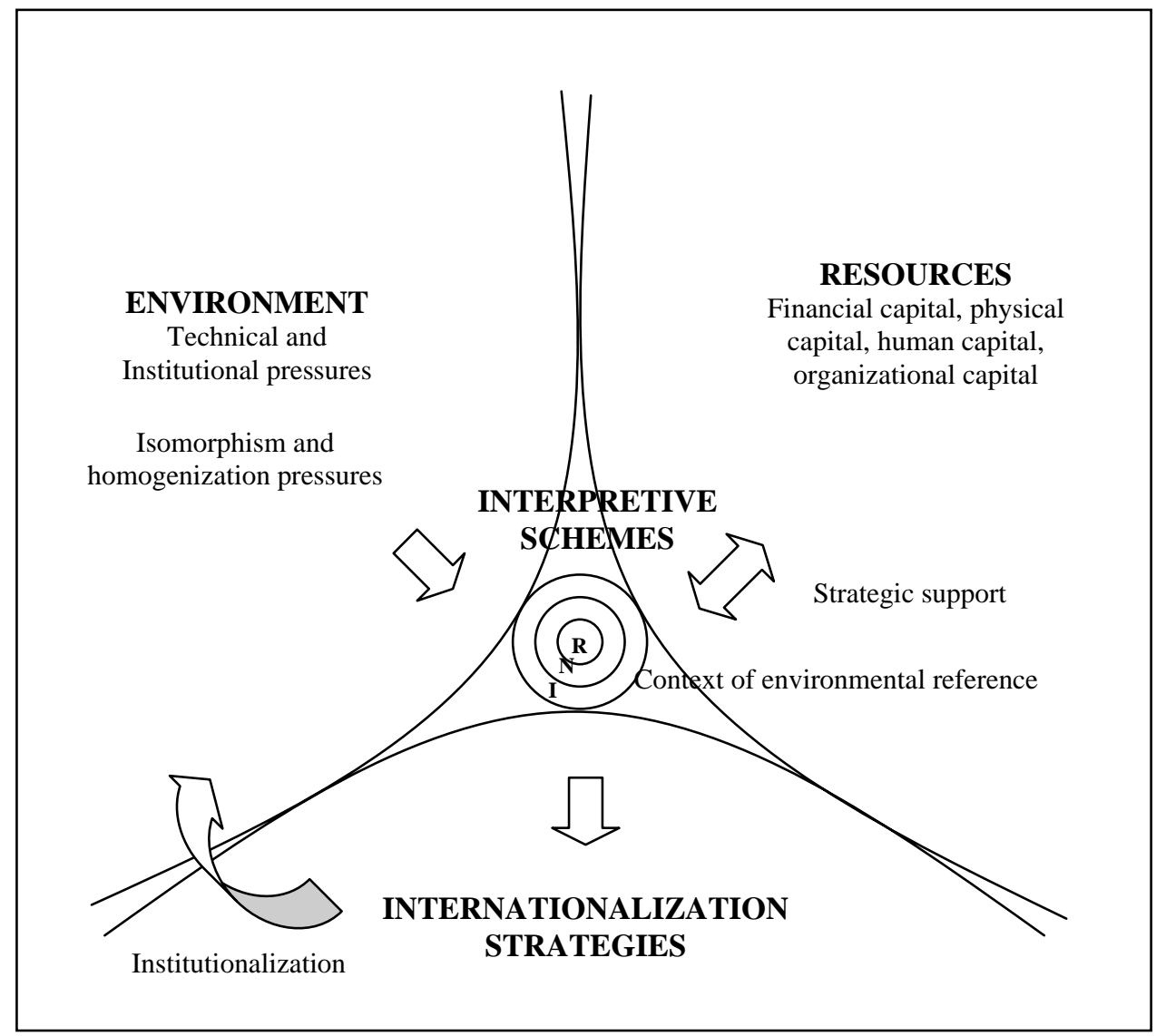

Source: Adapted from Machado-da-Silva; Seifert Jr., 2004 (Figure 2, p. 10).

As the model attempts to illustrate, we propose that internationalization strategies are cognitively processed by organizational members, especially those at the strategic level, in light of the environmental pressures and internal resources within the organization. Thus three elements are hypothesized to have influence on internationalization strategies: the environment, the resources, and the interpretive schemes.

Considering the role of the environment upon organizations, DiMaggio and Powell (1983) developed the thesis that organizations under the same environmental conditions are pressured to become homogeneous. They named that phenomenon isomorphism, which includes the process that leads organizations to adopt homogeneous practices among themselves. Additionally, DiMaggio and Powell (1983) state that pressures towards isomorphism can be of three main types: coercive, mimetic and normative. Coercive isomorphism is the result of formal and informal pressures, normally 
connected to political power such as the government or State, that organizations exercise on the others that depend upon them; furthermore, they can also be cultural expectations on certain organizational functions. Mimetic isomorphism is the imitation of behavior or organizational strategies for success, a phenomenon that usually happens in complex and uncertain environments. Normative isomorphism occurs when members of the same professional occupation promote the definition of methods and conditions for work and which later are disseminated as suitable norms of behavior. Still on the subject of environmental pressures, it seems important to draw a distinction between the institutional and technical facets of environment, a distinction originally proposed by Meyer and Rowan (1977). Although the proposed distinction is not clearly observable, Meyer and Rowan (1977) argued that the environment is composed of spaces of competition of both a technical (Hannan \& Freeman, 1978) and an institutional order. On technical competition, the operational efficiency and effectiveness of organizations is emphasized. On the institutional side, organizations compete for institutional legitimacy which provide stability and meaning for social behavior (Machado-da-Silva \& Fonseca, 1999).

Previous assumptions lead us to make our first proposition concerning the influence of the environment on internationalization strategies:

P1 - Organizations within the same industry will face technical and institutional coercive, mimetic and normative environmental pressures to adopt homogeneous and isomorphic internationalization strategies.

Whilst environmental pressures have for a long time been understood as the main explanatory variable on organizational strategy, authors have argued that the environment does not constitute the only determiner of strategies of organizational performance (Child, 1972, 1997). In this way, authors, especially within the resource-based view (Wernerfelt, 1984; Barney, 1991, 1996), claim that internal aspects, namely organizational resources, play an important role in the process of strategic elaboration and organizational performance. Usually, organizational resources are considered to be: assets, capacities, competences, organizational processes, attributes, information, knowledge and other internal attributes of the company. Amit and Schoemaker (1998, p. 203) suggest that resources can be defined as "stocks of available factors that are controlled by and are the property of a company". Considering the difficulties involved in identifying resources, authors began to conveniently classify them into different categories. Barney (1996) suggests four categories of resources: financial, physical, human and organizational. Financial resources include all types of monetary resources that companies can utilize to conceive and implement strategies. Physical resources correspond to physical technology used in the firm such as the industrial plant, equipment, geographic location or access to raw materials. Human capital includes training, experience, judgment, intelligence, relationships and the insights of managers and workers. Finally, organizational capital is an attribute of organizational collectiveness such as the organizational structure, systems of control and coordination, culture and reputation and informal relationships within groups inside the company and the company and its environment. The role of resources on organization leads to a second proposition:

P2 - Heterogeneity of resources among organizations within the same industry will lead towards differentiation in internationalization strategy.

The above proposition might seem naive on the point that the role of resources upon internationalization (e.g.: ownership advantages, experiential knowledge and others), has been discussed in the early theories in the field. However as pointed out by Tallman (2001) as well as Hitt et al. (2006), and observed in the introduction of this study, little is still known about the specific resources on which international expansion is based. For this reason, we attempted to investigate which kind of resources, whether financial, physical, human or organizational, were mainly linked to the differences in internationalization strategies. A complete list of measurements we used in each category is provided in the appendix.

A third dimension of our proposed model suggests that environmental pressures in addition to resource characteristics are subject to a cognitive filter, manifested by the interpretive schemes of the 
organizational leaders. That understanding agrees with the proposition of Daft and Weick (1984) that organizations do not possess any other mechanism other than individuals to define goals, process information or perceive the environment. In this way, it implies that the organizational cognitive system which underpins that process is critically linked to the organizational members at the strategic level. It leads to a third proposition outlined in the model.

P3 - Environmental pressures as well resource characteristics are subject to interpretation by a cognitive system characterized by the interpretive schemes of organizational members.

The existence of a common cognitive organizational system, the domain where strategic matters are outlined and defined is dubbed by Johnson (1987) as a paradigm in an analogy to the notion of a scientific paradigm proposed by Kuhn (1987). That stage of the cognitive theory is usually dealt with in the specialized literature under a variety of terms such as: paradigms, view of the world, schematization, organizational culture and interpretive schemes, to name a few (Bartunek, 1984). As Bartunek (1984) points out, despite the variation in terms, the basic assumption is that the same phenomenon or reality can be understood in different ways. We follow Hinings and Greenwood (1988) in the use of interpretive schemes notion to point out the idea of a common cognitive organizational system. As argued by Hinings and Greenwood (1988) the interpretive schemes concept means that a set of beliefs, values and ideas guide organizational decision, condition what the organization does and how it does it. Additionally it guides judgments of value related to the interpretation process. Therefore, we emphasize that the use of an interpretive schemes notion implies the idea of a shared cognitive domain which influences how individuals perceive and understand their organizations, at the same time that is indicates how they should act under certain circumstances. In that way the notion of interpretive schemes highlights the role of shared values and beliefs. Values are here accessed by the criteria, conceptions or rationalized preferences of determined action. Beliefs are understood as the unconscious assumption that brings expectations to individuals with variations in intensity and which influence perceptions, thoughts and emotions (Machado-da-Silva \& Fonseca, 1994).

The understanding that interpretive schemes can be accessed in terms of values and beliefs raises another important observation. It is the assumption that there is a link between the values and beliefs that compose the interpretive schemes within an organization, and the values and beliefs present in certain contexts of social reference. That idea remains to Simon (1979) proposition that values and beliefs, elementary cognitive elements in the rational decision model, are not formed or discovered by rational optimum calculation; otherwise they originate in the social domain, and it is from there that they are internalized into the minds of individuals through socialization and interaction. With that rationale in mind we point to the relevance of contexts of environmental reference (Machado-daSilva, Fonseca, \& Fernandes, 2000). This idea implies the existence of social domains of reference from which values and beliefs are apprehended and retained in the knowledge and interpretation structure (interpretive schemes) shared among the organizational members. Additionally it implies that members of the same population, or organizations in the same industry, might present a variation within the social environmental context which they have for reference. In this way, the possibilities of variation concerning contexts or levels of environmental reference among organizations of the same population will be essential elements conditioning the strategic action heterogeneity among them. For the purposes of this study, we proposed an analytical division of three main contexts of environmental reference: regional, national and international. Under these circumstances we are able to make the final propositions concerning the role of cognition and interpretation in internationalization strategies.

P4 - Organizations within the same industry will vary in terms of the environmental contexts (regional, national and international) they have for reference.

P5 - Variation in terms of environmental contexts of reference imply a variation in terms of internationalization strategies among organizations within the same industry. 


\section{ResearCh Methods ANd Procedures}

Considering the conceptual analytic model presented, and aiming to verify the role of environmental pressures and resources mediated by the interpretive schemes on internationalization strategies, we decided to conduct the study within the Brazilian food industry in Paraná State. Several reasons led us to choose the food industry and Paraná State: i) the relevance of the food industry in Paraná State; ii) the availability of secondary data to map regional, national and international contexts of environmental reference within that industry; iii) the importance of the food industry in Paraná's international trade.

The research was conducted in two main phases. In the first we aimed to map and identify values and beliefs shared within the food industry in the three main contexts of reference previously informed in the theoretical background: regional, national and international. In the second we conducted a survey within the Brazilian food industry of Paraná State.

In order to identify values and beliefs shared in each environmental context of reference we used secondary data about the food industry at the three main levels: regional, national and international. For that we focused on relevant information published between 2000 and 2003 in newspapers, business magazines, industry reviews, reports from Confederação Nacional da Indústria - CNI (The National Confederation of Industry), Banco Central - BC (The Brazilian Central Bank), and Banco Nacional de Desenvolvimento - BNDES (The National Bank for Development), Union reports, books about the industry and a report from Associação Brasileira das Indústrias da Alimentação - ABIA (The Brazilian Food Industry Association). On doing so, at the first step we used document analysis to select and classify data which resulted in the selection of 63 documents. In the second step of analysis we applied the procedures of content analysis focused on the frequency of the occurrence and relevance of identified factors. In the third step we focused on identifying the values and their attached meanings in each context of the environmental reference.

The second phase of this study included a survey conducted in late 2003 and early 2004 within the food industry of Paraná State, Brazil. According to the Annual Records of Social Information (RAIS), the population of firms in the food industry with more than twenty employees and operating in the State of Paraná comprised 448 firms. A questionnaire focusing on the internationalization process, resources and environmental context of reference was sent by mail and addressed to the main leader at the strategic level for all the firms listed. Fifty-two questionnaires were returned, which means a response rate of $11.6 \%$. Due to limitations in view of the low response rate and sample, we opted for the use of non-parametric statistic tests. Sources, measurement and analytical issues related to the dependent and independent variables are explained below.

Internationalization process. Primary data related to the internationalization process of companies were collected in order to identify and group companies with similar strategic patterns of internationalization. The methodological and analytical procedures were based on the following set of information: a) the date that the company was founded; b) foreign inward and outward cross-border links made by the firm since its foundation; and c) the year in which each cross-border link was established for the first time. In order to group companies with similar patterns in terms of internationalization strategies, we sought the support of cluster analysis provided by statistical packages. Nevertheless, that effort was ineffective due to the requirement of producing nominal and interval analyses of internationalization events simultaneously. Faced with these limitations, we opted for the qualitative organization and manipulation of data at this stage, following the same procedures reported by Jones (1999) facing similar difficulties.

Resources. As observed in the model presentation we sought to verify the influence of four different categories of resources in internationalization. Financial resources were accessed in terms of: total sales, percentage of production growth in the last three years, frequency of requiring financial help for funding production issues, and the use of governmental financial credits for production investment. Physical resources were measured in terms of: the average age of production machines and equipment, principal product production capacity and productivity. Human resources were measured 
in terms of: the number of people responsible for strategic decision making in the firm, average years of managers' experience in the food industry, educational qualifications, international experience and foreign language skills. Organizational resources were measured in terms of: the number of new products put on the market in the last three years, percentage of total sales invested in marketing issues, risk perception, the degree of partnership relationship with members of the production chain, size and age. Measurements used seven-point Likert scales, ordinal, nominal, continuous and discrete measurements. See appendix for a detailed view of resource variable measurements.

Environmental context of reference. The environmental context of reference, which means the visualization domain of technical and institutional facets of environment by the organizational members at the strategic level, whether regional, national or international, was accessed in the following way. Based on the environmental description and identified values of each domain in the first phase of this research, seven multiple choice questions were developed as pointing parameters of the environmental context of reference attached to the interpretive schemes shared within the organization. Thus, for each question there were three possible answers, each referring to a specific domain of reference (regional, national or international) in an exclusive way.

\section{RESULTS AND ANALYSIS}

\section{The General Brazilian Environmental Context of the Food Industry}

Traditionally, Brazil has been characterized as a relatively closed economy when it comes to issues related to international trade. For several decades, protectionist policies kept Brazilian industrial environment apart from the most technological and organizational transformations that were taking place at the international level. As a result, at the same time it privileged a business environment free from international competition, it also favored the development of a production mentality focused on the domestic market. It was only during the 1990s that a new political and commercial mentality arose in the country. It left aside at least four decades of protectionist tradition and promoted a new cycle of growth-based open markets ideas, which resulted in significant technical and institutional changes in Brazilian business environment. In this section, we aim to address some of the main aspects that characterized the environmental context surrounding the internationalization strategies of companies studied in our research. The underlying logic is that the institutional and technical characteristics of the environment played an important role in internationalization strategies.

In the late 1980s, a broad revision of the tariff structure that ensured protection against imports was set in motion in the Brazilian economy. However it was only during the President Fernando Collor de Mello administration, in the early 1990s, that the system of industrial and overseas trading policy was simplified, a considerable number of non-tariff barriers were eliminated and a chronogram for the systematic reduction of import tariffs was defined. The result was that the average rate of import tariffs, which in 1988 was 51\%, fell to $13.1 \%$ in 1995 (Averbug, 1999). Additionally, the macroeconomic situation in the country, which in the early 1990s could be characterized by high and rising inflation, fiscal deficit, devaluated currency and a weak international position, had undergone significant changes by the mid nineteen nineties. The stabilization program named 'Plano Real' reduced inflation rates from over $40 \%$ per month in June 1994, to under $2 \%$ by the end of the same year. The exchange rate was healthier and favored an increased widening of deficits in the balance of trade and services (Pinheiro, Giambiagi, \& Gostkorzewicz, 1999) due to growing imports. The process of commercial deregulation bolstered integration with neighboring countries and improved relations within Mercosur. A great privatization program was undertaken in the country leading to a greater inflow of FDI. Coercive regulation pressures were substantially reduced and the increasing commercial freedom, especially in terms of international trade, changed the patterns of competition in the country. 
In the food industry, the increasing buying power of consumers during the mid 1990s led to the rise in consumption of products with a higher aggregate value. After thirty months of stabilization since 1994, the food industry grew by 15.4\% in physical production (Abia, 2002). Between 1994 and 2001, the consumption of some food products grew by over $70 \%$. For example, chicken consumption grew 75.3\% and yogurt 72.7\% (Abia, 2002). This led to a new cycle of investments in the Brazilian food industry, mainly characterized by imports and the substitution of machines and equipment in order to modernize productive plants (Favaret Filho \& Paula, 2003). The dimensions of and the opportunities available to the Brazilian food market attracted the attention of multinational companies. The number of mergers and acquisitions in the food sector increased, leading to substantial concentration in the sector. Data from BNDES (1999) indicate that in the sector of food, drink and tobacco, the number of mergers and acquisitions between 1992 and 1998 accounted for 13\% of the total.

Considering the nature of changes that faced Brazilian economy especially during the 1990s, it seems quite evident that it had influences on the internationalization strategies of firms in the food industry. On the other hand, from the theoretical background that supports this study, we have argued that organizations might differ systematically in the way they interpret the environment and the changes that have taken place. Considering the role of interpretive schemes, we have proposed that organizational members can apprehend values and beliefs that guide action from different domains of reference, namely regional, national or international contexts. Additionally we have argued that the attached meanings to values in each of those domains of reference might differ and will thus lead to different courses of international action. In the next section we present the values and attached meanings for each one of the three environmental contexts of reference studied for the food industry: regional, national and international.

\section{Regional, National and International Contexts of Reference in the Food Industry}

The efforts of our research here aimed to identify the values and attached meanings that underline the logic of action and serve as a source of reference for the interpretive schemes of organizational members. The 'regional context' accounts for values and meaning shared within the Paraná State business domain. The 'national context' accounts for the Brazilian general domain of reference, and 'international context' for the foreign general domain. We must account for the fact that on some occasions there was great difficulty in carrying out this task due to the contextual limits among reference domains not being explicit, and often confusing.

Owing to space limits, it would not be possible to reproduce the complete description of the environmental characteristics for each of the contexts of analysis. We sought to minimize that limitation using self-explanatory tables. On so doing, in Table 1 we first present the main changes in the regional, national and international contexts of analysis. 
Table 1: Main Differences among Contexts of Environmental Reference

\begin{tabular}{|c|c|c|c|}
\hline \multirow{2}{*}{ Factor } & \multicolumn{3}{|c|}{ Context } \\
\hline & $\begin{array}{l}\text { International } \\
\end{array}$ & Domestic & Regional \\
\hline Scope/perspective & - World/global & - Brazil & - Paraná \\
\hline Population Growth & $\begin{array}{l}\text { - Slow growth with a } \\
\text { tendency to reduce in the } \\
\text { long term. }\end{array}$ & $\begin{array}{l}\text { - On average higher than the } \\
\text { world population. } \\
\text { Declining trend in the long } \\
\text { term. }\end{array}$ & $\begin{array}{l}\text { - Declining trend in the } \\
\text { long term. Generally } \\
\text { follows trend of the } \\
\text { country as a whole. }\end{array}$ \\
\hline Food Market & $\begin{array}{l}\text { - Oligopolized/concentrated. } \\
\text { - Competition for prices and } \\
\text { resources } \\
\text { - High rate of competition. }\end{array}$ & $\begin{array}{l}\text { - Broad and accessible } \\
\text { - Gradual expansion has } \\
\text { guaranteed growth in the } \\
\text { industries in this sector } \\
\text { - Tendency towards } \\
\text { concentration } \\
\text { - Increased competition with } \\
\text { imports and new entries. }\end{array}$ & $\begin{array}{l}\text { - Follows country’s } \\
\text { trend }\end{array}$ \\
\hline Consumer behavior & $\begin{array}{l}\text { - Reduction of costs with } \\
\text { food products } \\
\text { - High level of quality } \\
\text { demand } \\
\text { - International consumer } \\
\text { standard. }\end{array}$ & $\begin{array}{l}\text { - Demand for products with } \\
\text { higher aggregate value } \\
\text { - Specifications of domestic } \\
\text { consumption. }\end{array}$ & $\begin{array}{l}\text { - Follows national trends } \\
\text { with regional specifics. }\end{array}$ \\
\hline $\begin{array}{l}\text { Determining factor } \\
\text { of the product }\end{array}$ & $\begin{array}{l}\text { - Value (low quality and } \\
\text { cost), brand and } \\
\text { convenience } \\
\text { - Food safety } \\
\text { - Health foodstuff } \\
\text { - Ecologically correct. }\end{array}$ & - Low cost and quality. & - Low cost and quality. \\
\hline Role of the State & $\begin{array}{l}\text { - Regulate and control illegal } \\
\text { trading practices } \\
\text { - Lower barriers and } \\
\text { facilitate international } \\
\text { trade. }\end{array}$ & $\begin{array}{l}\text { - Develop industrial policies } \\
\text { that favor production and } \\
\text { commercialization and } \\
\text { comparative advantages for } \\
\text { the country } \\
\text { - Support and defend } \\
\text { domestic industry }\end{array}$ & $\begin{array}{l}\text { - Stimulate regional } \\
\text { industry through } \\
\text { subsidies and tax } \\
\text { incentives } \\
\text { - Attract investment to } \\
\text { the state. }\end{array}$ \\
\hline $\begin{array}{l}\text { Focus of attention of } \\
\text { NGOs }\end{array}$ & $\begin{array}{l}\text { - Marketing practices that } \\
\text { stimulate consumption of } \\
\text { foodstuffs that lead to } \\
\text { illnesses in modern society } \\
\text { - Pressure for more } \\
\text { information on labels and } \\
\text { packaging of foodstuffs } \\
\text { - Food safety. }\end{array}$ & $\begin{array}{l}\text { - Consumer rights } \\
\text { - Quality of products and } \\
\text { productive processes } \\
\text { - Commercial balance } \\
\text { between producers, } \\
\text { industries and retailers. }\end{array}$ & $\begin{array}{l}\text { - Follows nationwide } \\
\text { trend with regional } \\
\text { specifics and } \\
\text { variations. }\end{array}$ \\
\hline
\end{tabular}

Source: Secondary research data.

Table 1 points out the existence of fundamental differences among the three levels of analysis of the environmental context. Additionally, it underpins the existence of different meanings and understandings for values shared in each context, as presented in Table 2. 
Table 2: Values and Attached Meanings in the Three Environmental Contexts of Reference

\begin{tabular}{|c|c|c|c|}
\hline \multirow{2}{*}{ Values } & \multicolumn{3}{|c|}{ Meanings/understandings in each context } \\
\hline & International & Domestic & Regional \\
\hline $\begin{array}{l}\text { Valued strategic } \\
\text { activity }\end{array}$ & $\begin{array}{l}\text { - Pro-activity } \\
\text { - Expansion and } \\
\text { international } \\
\text { consolidation }\end{array}$ & $\begin{array}{l}\text { - Adaptation } \\
\text { - Expansion and domestic } \\
\text { consolidation. }\end{array}$ & $\begin{array}{l}\text { - Adaptation } \\
\text { - Expansion and regional } \\
\text { consolidation. }\end{array}$ \\
\hline $\begin{array}{l}\text { Managerial } \\
\text { competence }\end{array}$ & $\begin{array}{l}\text { - Pro-activity, creativity, } \\
\text { analytical capacity for } \\
\text { decision-making. }\end{array}$ & $\begin{array}{l}\text { - Rapid reaction } \\
\text { - Ability for adjustment } \\
\text { and adaptation to market } \\
\text { changes, new } \\
\text { technologies etc. }\end{array}$ & $\begin{array}{l}\text { - Capacity and ability for } \\
\text { control, coordination and } \\
\text { sales. }\end{array}$ \\
\hline Product & $\begin{array}{l}\text { - High degree of } \\
\text { differentiation. }\end{array}$ & $\begin{array}{l}\text { - Medium degree of } \\
\text { differentiation }\end{array}$ & $\begin{array}{l}\text { - Standardization and scale } \\
\text { production. }\end{array}$ \\
\hline Internationalization & $\begin{array}{l}\text { - Multi-nationalization, } \\
\text { Joint ventures } \\
\text { - International agreements } \\
\text { and contracts } \\
\text { - High degree of } \\
\text { commitment. }\end{array}$ & $\begin{array}{l}\text { - Exports, imports } \\
\text { - Focus on commercial } \\
\text { sales and purchase } \\
\text { operations } \\
\text { - Medium commitment. }\end{array}$ & $\begin{array}{l}\text { - Low valuation } \\
\text { - Focus on domestic activity } \\
\text { - Low commitment. }\end{array}$ \\
\hline Marketing & $\begin{array}{l}\text { - Suitability for } \\
\text { international consumer } \\
\text { standards } \\
\text { - Discipline for } \\
\text { development and } \\
\text { strengthening of the } \\
\text { brand. }\end{array}$ & $\begin{array}{l}\text { - Suitability for domestic } \\
\text { consumer } \\
\text { - Instrument for } \\
\text { segmentation and access } \\
\text { to market niches. }\end{array}$ & $\begin{array}{l}\text { - Suitability for regional } \\
\text { consumer standards } \\
\text { - Commercial promotion. }\end{array}$ \\
\hline Modernization & $\begin{array}{l}\text { - Development of new } \\
\text { technologies } \\
\text { - Broadening uses of } \\
\text { applications of } \\
\text { telecommunications with } \\
\text { focus on the INTERNET } \\
\text { - Robotization and } \\
\text { automation of production }\end{array}$ & $\begin{array}{l}\text { - Adaptation to new } \\
\text { technologies } \\
\text { - Acquisition of machinery } \\
\text { and imported equipment. } \\
\text { - Automation of more } \\
\text { complex productive } \\
\text { processes. }\end{array}$ & $\begin{array}{l}\text { - Incipient concern towards } \\
\text { a trend of repetition of } \\
\text { forms and standards } \\
\text { - Low rate of automation in } \\
\text { the productive process. }\end{array}$ \\
\hline Internet & $\begin{array}{l}\text { - Wide use } \\
\text { - Tool for B2B and B2C } \\
\text { relating } \\
\text { - Applications of electronic } \\
\text { trade. }\end{array}$ & $\begin{array}{l}\text { - Means of communication } \\
\text { between company and } \\
\text { suppliers } \\
\text { - Means of institutional } \\
\text { divulging of the company } \\
\text { and its products. }\end{array}$ & - E-mail. \\
\hline Productivity & $\begin{array}{l}\text { - Efficiency and agility } \\
\text { (automation) of } \\
\text { production process. }\end{array}$ & $\begin{array}{l}\text { - Production techniques } \\
\text { that aim to reduce costs } \\
\text { and waste. }\end{array}$ & $\begin{array}{l}\text { - Maximization of } \\
\text { production at lowest cost. }\end{array}$ \\
\hline $\begin{array}{l}\text { Ecological } \\
\text { responsibility }\end{array}$ & $\begin{array}{l}\text { - Awareness and ecological } \\
\text { action with a high degree } \\
\text { of use ecologically } \\
\text { correct raw materials. }\end{array}$ & $\begin{array}{l}\text { - Moderate concern with } \\
\text { use of ecologically } \\
\text { correct raw materials. }\end{array}$ & - Incipient concern. \\
\hline Cooperation & $\begin{array}{l}\text { - Focus on strengthening } \\
\text { industries (sectors), } \\
\text { reducing competition and } \\
\text { carrying out research and } \\
\text { development } \\
\text { - Close relationship } \\
\text { interlinked with diverse } \\
\text { elements of the } \\
\text { production chain. }\end{array}$ & $\begin{array}{l}\text { - Focus on reducing } \\
\text { competition, increasing } \\
\text { participation of the } \\
\text { market and guaranteeing } \\
\text { scale gains } \\
\text { - Essentially commercial } \\
\text { relationship. }\end{array}$ & $\begin{array}{l}\text { - Low valuing. Focus on } \\
\text { optimizing production. }\end{array}$ \\
\hline Low cost & - Focus on search for & - Focus on maximum & - Focus on possibility of \\
\hline
\end{tabular}




\begin{tabular}{|c|c|c|c|}
\hline & $\begin{array}{l}\text { opportunities and gains } \\
\text { through efficiency of } \\
\text { logistics systems and } \\
\text { addition of product } \\
\text { values. }\end{array}$ & $\begin{array}{l}\text { utilization of production } \\
\text { capacity, transport and } \\
\text { administration of public } \\
\text { tariffs. }\end{array}$ & $\begin{array}{l}\text { vertical integration, } \\
\text { transport costs and labor. }\end{array}$ \\
\hline Competitiveness & $\begin{array}{l}\text { - Organizational and } \\
\text { industrial (sector) } \\
\text { restructuring } \\
\text { - Cooperative relationship } \\
\text { with elements in the } \\
\text { productive chain. }\end{array}$ & $\begin{array}{l}\text { - Reflection of public } \\
\text { policies of production, } \\
\text { investments in } \\
\text { infrastructure, elevation } \\
\text { of internal consumption, } \\
\text { reorganization of } \\
\text { production and the } \\
\text { productive chain. }\end{array}$ & $\begin{array}{l}\text { - Reflection of state’s public } \\
\text { policies, subsidies and } \\
\text { incentive } \\
\text { - Scale production and low } \\
\text { cost per unit. }\end{array}$ \\
\hline Human Resources & $\begin{array}{l}\text { - Link or connection } \\
\text { between modernization } \\
\text { and performance of the } \\
\text { organization } \\
\text { - High rate of training and } \\
\text { specialization. }\end{array}$ & $\begin{array}{l}\text { - Extension of fixed capital } \\
\text { of the organization } \\
\text { - Medium degree of } \\
\text { specialization and labor } \\
\text { training. }\end{array}$ & $\begin{array}{l}\text { - Necessary element for } \\
\text { production. Low level of } \\
\text { qualification } \\
\text { - Low rate of investment in } \\
\text { training and } \\
\text { apprenticeships. }\end{array}$ \\
\hline Quality & $\begin{array}{l}\text { - Essential factor for } \\
\text { market participation } \\
\text { - Characterizes the } \\
\text { organization and its } \\
\text { production chain. } \\
\text { - Focus on quality of } \\
\text { products and components } \\
\text { - Printed on international } \\
\text { quality certifications. }\end{array}$ & $\begin{array}{l}\text { - Factor of competitive } \\
\text { differentiation linked to } \\
\text { consumer demands } \\
\text { - Focus on quality of the } \\
\text { end product and raw } \\
\text { materials with an } \\
\text { emphasis on inspection } \\
\text { and productive process } \\
\text { control. } \\
\text { - Medium concern with } \\
\text { quality certifications. }\end{array}$ & $\begin{array}{l}\text { - Factor of competitive } \\
\text { differentiation } \\
\text { - Focus on the quality of the } \\
\text { product } \\
\text { - Little concern with } \\
\text { certifications. }\end{array}$ \\
\hline
\end{tabular}

Table 2 demonstrates that the meanings attached to values in the environmental context of the food industries vary according to their context of reference (regional, national \& international). As already argued by Machado-da-Silva and Barbosa (2002), it supports the assumption that organizational action might vary in accordance with the environmental context organizational members have for reference, be it regional, national or international. For instance, we notice that internationalization may have three different meanings or understandings depending on the context in which it is contained. At the international level, internationalization is attached to the role of globalization, multinational firms, high commitment international operations and international management. At the national level, internationalization means international trade focused on exports and imports. Finally, at the regional level, meanings attached to internationalization manifest its weak importance and are usually linked to operations of low international commitment and involvement.

In the next sections we focus on results pertaining to the strategic patterns of internationalization, followed by firms in the food industry of Paraná.

\section{Strategic Patterns of Internationalization}

Three main strategic patterns of internationalization were found in the sample: domestic action, reluctant internationalization and active internationalization. The group named domestic was constituted by companies with no international involvement (18 cases). The existence of a group of companies which presented no international involvement, was relevant in that it served as a yardstick for comparison. In that way it helped us in analyzing factors that could explain why such companies had any international involvement.

The second group was named reluctant and was composed of food industry firms which, despite 
some international involvement, avoid higher external commitment and involvement (14 cases). Their international operations focused mainly on indirect commercial activities (exports and imports) carried through intermediary agencies such as trading companies or import and export agents. Furthermore, companies within the reluctant group have a low degree of internationalizing events, two on average. Additionally they oscillate between moments or years of international activity and years of no international activity.

Companies from the active group (20 cases) presented cross-border links which manifested greater involvement and commitment. In addition to this, they had an average of seven internationalizing events. The international strategic logic of these companies is revealed by the predominance of outward direct commercial activities (e.g. export), supported by marketing activities in Brazil and abroad. Although most of the sales of the firms within this group come from the domestic market, they consider the overseas market and international operations to be quite significant and attach some importance to them. Whilst they greatly rely on trade operations, the international involvement of these companies also includes activities of greater complexity and involvement such as partnerships and foreign direct investment. Therefore, the external links of firms within this group are not restricted to trade activities as is the case of the operations of firms from the reluctant group.

It is worth noting that the strategic patterns identified are not understood as internationalization stages. In other words, we maintain that each group might represent specific strategic choices conditioned by the environmental pressures, resources and interpretive schemes. In the next section we present the resource characteristics that distinguish each one of the firm groups identified in the Paraná food industry.

\section{Resources}

Considering the four categories of resources and the 18 measurement indicators, we found significant differences at the level 0.05 among the groups in five resource indicators: a) two related to financial resources; b) one to physical resources; c) one to human resources; and d) one related to organizational resources. For a complete view of the resource indicators and statistics test conducted, please see the appendix.

Considering the financial resources, we found that companies with greater international involvement have higher total sales and usually access more financial government credits for funding investment. In terms of physical resources, we observed that firms from the active internalizing strategy group have higher production capacity installed. Further we found that this characteristic is linked to the fact that companies within the active group are bigger in size. In terms of human resources, managers within the active group have higher educational qualifications than the managers from the domestic and reluctant groups. Concerning organizational resources, we found, as earlier observed, that firms within the active group are bigger in size. Here this was measured by the number of employees. However, as observed before, they are also bigger when size is measured in terms of total sales. Additionally, firms with more international involvement place more importance on international action.

From these findings, three aspects seem to have greater relevance in explaining the internationalization strategies in the companies studied: a) size; b) ability to acquire financial capital; c) educational qualifications of managers. We opted for not discussing the influence of total sales and production capacity once the superiority of these indicators is implicit on size.

\section{The Environmental Context of Reference}

We found that the environmental context of reference varies among firms of the different groups (domestic, reluctant and active). We present this variation in Figure 2. 
Figure 2: Scope of Environmental Context of Reference

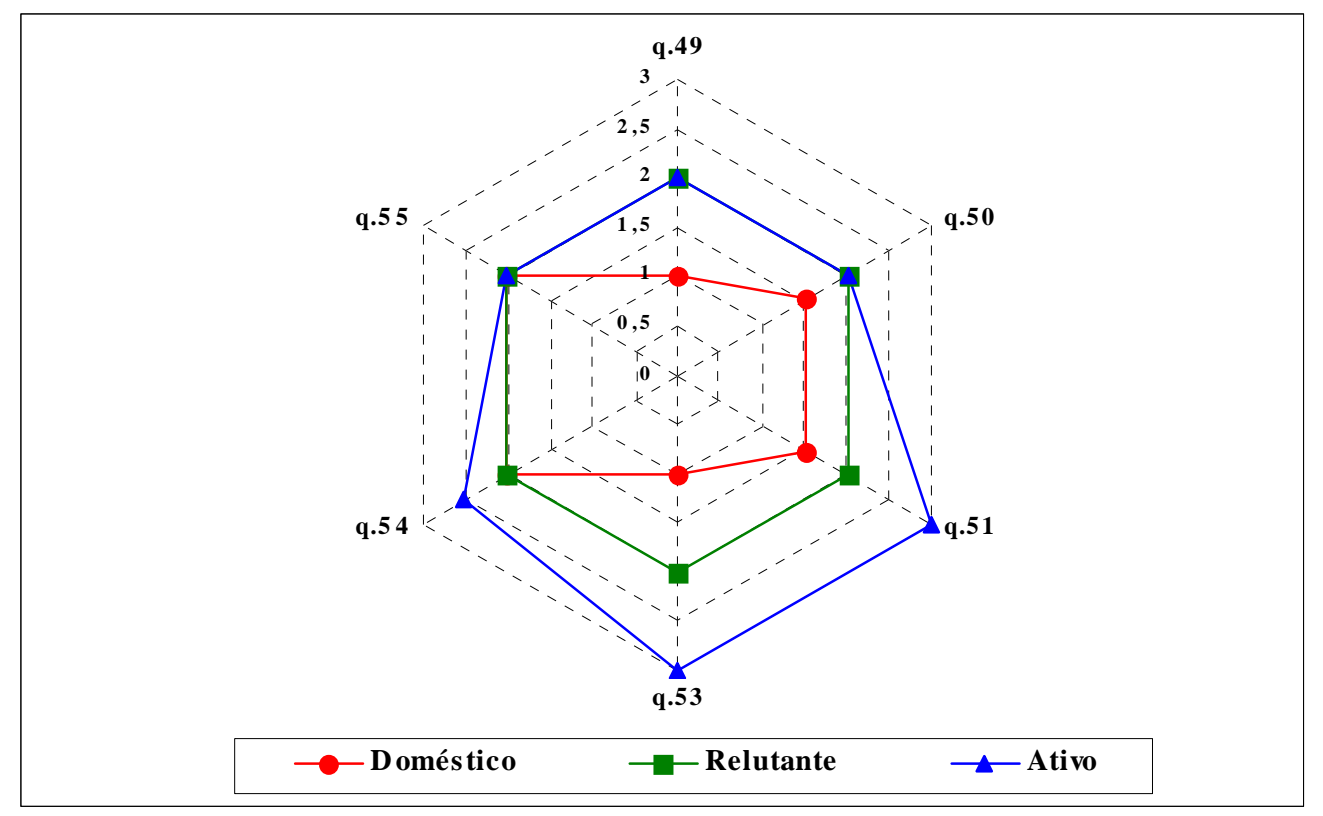

Note: Median differences significant at $\mathrm{p}=0,05$ between the domestic and reluctant groups $(\mathrm{M}-\mathrm{W}=$ $6.000 ; \mathrm{p}=0.022)$, and domestic and active $(\mathrm{M}-\mathrm{W}=3.000 ; \mathrm{p}=0.012)$. Median differences between the reluctant and active groups are significant at level $\mathrm{p}=0.1(\mathrm{M}-\mathrm{W}=9.000 ; \mathrm{p}=0.058)$.

As pointed out in Figure 2, the interpretive schemes in firms of the domestic group had to do with the regional context. The interpretive schemes in firms of the reluctant group appeared a little bit wider in that they were to be taken within the national context. Finally, within the active group, it appears to be a mixture of references to the national and international context.

In order to test the correlation between the groups and the environmental context of reference, we conducted the Spearman test of medians. The results evidenced a significant (p 0.001), positive correlation (Spearman value correlation: 0.762) between them. This statistical correlation is enhanced when the convergence between values and attached meanings in each environmental context of reference (regional, national and international) and the effective international involvement of the food industries sampled is noted. For example, companies from the domestic group, in which interpretative schemes are referenced in the regional context, had no engagement in international activities. On the other hand, firms from the active group, with interpretive schemes referenced in the national/international context, were shown to have greater involvement and engagement in international operations.

\section{Discussion}

In this section, we aim to discuss the results concerning the influences of the environment, resources and interpretation on the internationalization process of the food industry firms sampled in the light of previous theoretical model of analysis. In that way we sought to gain some insights into the debate on homogeneity, heterogeneity and organizational agency in internationalization strategy.

Regarding environmental influences, our first proposition was that organizations within the same industry would face technical and institutional coercive, mimetic and normative environmental pressures to adopt homogeneous and isomorphic internationalization strategies. In that way isomorphism mechanisms may be understood as elements of facilitation or restriction in the internationalization process. Our findings support that proposition as we noticed that technical and institutional changes in the Brazilian food industry environment influenced the time gap between the foundation of firms and the beginning of their internationalization process. As we observe in Table 3, 
we found significant evidence (p 0.001) that firms from the active group founded prior to 1990 began internationalizing after an average of 20 years, whereas firms founded after 1990 started internationalizing after an average of just three years.

Table 3: Gap between Foundation and First Cross-border Link

\begin{tabular}{cccccccccc}
\hline Subgroups & $\mathbf{n}$ & Mean & Median & Sd & Min & Max & Stat Test & Value Test & Sig (p) \\
\hline A & 7 & 3 & 3 & 1,15 & 1 & 4 & & & \\
B & 12 & 20,4 & 20,4 & 6,63 & 8 & 34 & & & \\
\end{tabular}

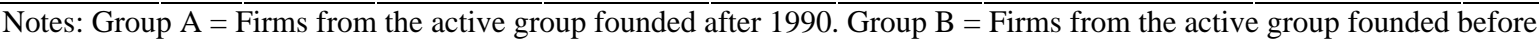
1990

We argue that companies founded after 1990 were embedded in an environmental context which was more favorable for internationalization, by which we mean a context with lower governmental coercive pressures, and with a substantially new institutional competitive context which was mainly made up of international competition. Conversely, firms founded before 1990 emerged in a protected environment and with greater coercive regulations upon international trade, which made internationalization a difficult process. Additionally, to better exemplify homogenization pressures upon internationalization we observed that no firm from the reluctant group established any international operation before 1990, even taking into account that most of them were founded before 1990. Therefore, even considering the limitation of this study, it points out the need to understand better the role of technical and institutional pressures on internationalization, mainly when it shows that internationalization is not merely a rational economic choice. On the contrary, as Kogut and Zander (2003a) claimed, the national institutional environment matters when it comes to international trajectories.

However, as our second proposition has claimed, internationalization strategies are not exclusively conditioned by the environment. If that were indeed so, resource heterogeneity among organizations would lead to strategy differentiation for internationalization. We found significant differences in three main resource indicators among firms with different internationalization strategies (domestic, reluctant and active): size, capacity to acquire financial capital and educational qualification of main managers. Therefore, larger organizations with greater capacity for acquiring financial capital and with more and better qualified managers appear to have higher international commitment and involvement.

To discuss the role of size in internationalization is not an easy thing, particularly when we realize that studies have turned up controversial results. Organizational size can be understood as an expression of the superiority or inferiority of certain organizational resources and capacities. In other words, a bigger size might indicate more resources in terms of financial activity, bargaining power, capacity for risk taking and physical resources. Nevertheless, it might actually conceal some traps, especially if it is argued that small firms cannot internationalize. Although size, as an expression of superiority of resources, might be relevant to internationalization, we must bear in mind Calof's (1993) observation that size does not constitute a barrier to internationalization. Several concerns involving size could not be attained in this study, and these should be kept as a control variable in further studies. Regarding size, what seems interesting is the observation that internationalization is a process related to the growth of firms, as observed by Jones (1999). In other words, as the organization grows, it tends to engage in internationalization. However, care should be taken with this observation since some companies do not grow in terms of size but internationalize nonetheless. Besides, as this study demonstrates, some firms might grow in terms of size but, due to environmental constraints, they do not internationalize, or only internationalize when the environment is favorable.

Although the role of size as an indicator of the superiority of resources might be difficult to interpret, the capacity to acquire financial capital and the educational qualification of managers might afford us a clearer interpretation. As Westhead, Wright and Ucbasaran (2001) previously highlighted, the ability to acquire financial capital, thereby increasing the availability of financial resources, provides 
organizations with the opportunity to pursue a wider range of activities as well as undertake more ambitious projects. The availability of financial resources encourages investments of intensive capital, facilitates entry into new markets, increases bargaining capacity, enhances legitimacy and brings others benefits. Additionally it contributes to removing financial barriers that involve the beginning of the internationalization process and consequently promotes organizational growth. At the same time, human resources, in terms of the educational qualification of managers, appear to play an important role in internationalization. As Cooper, Gimeno-Gascon and Woo (1994) have pointed out, educational qualification is related to greater knowledge, capacities, problem solving abilities, discipline, motivation, self-confidence and other skills. The further managers go in obtaining educational qualifications, the more they are exposed to instruments, techniques, concepts, tools, beliefs and values that are usually widely shared and accepted within the international context of reference of business management. In that way, as previously observed the international context of reference attaches greater meanings to involvement and engagement in international operations. For example, concepts such as globalization, transnationality, international alliances, global supply chain, international joint-ventures, to name a few, are usually topics discussed in all MBA programs. Thus, the immersion in the context of higher business educations tends to support practical applications of such a context within organizational reality. In that direction Westhead, Wright and Ucbasaran (2001) observed that leaders with university education have wider business expectations and greater networks of social and business relationships. Therefore, the finding that managers within the active group have higher levels of educational qualification supports the assumption about the positive association between internationalization and education.

Nonetheless, considering the nature of resources influence on internationalization strategies, it seems to be rather different from the influence of the environment. Whilst environmental pressures act as contingency factors, to which internationalization strategies are subjected and to a certain degree are dependent, resources are factors that support and make internationalization strategies possible. In that way, the greater the resource availability the less environmental dependence there will be and viceversa. Therefore, our findings give support to the resource-based view assumption that variations in terms of resources possessed among organizations account for their strategic differences and performance differences. However it leads to another question: how do organizations within the same industry and under similar environmental pressures develop different resources or have different understandings concerning a similar reality? This question leads to our propositions about the role of interpretive schemes and their cognitive mediation of the internationalization strategic process.

In our theoretical model we proposed that environmental pressures and resources are the subject of a cognitive process guided by the interpretive schemes of organizational members. Thus, our assumption was that despite the fact that organizations are pressured towards environment isomorphism, as argued by the institutional theory (Meyer \& Rowan, 1977; DiMaggio \& Powell, 1983), organizational heterogeneity prevails because of the diversity and specificities of interpretive schemes among organizations even in the same industry. As pointed out previously, we found empirical support for the assumption that organizations cognitively differ in their environment. In other words, we observed that organizations conceive and delimit cognitively different contexts (regional, national and international) for action. At the same time, this corroborates our fourth proposition, supporting pioneer Weick's (1969) statement that people in organizations enact their environments. Furthermore, it supports Child's $(1972,1997)$ model of strategic choice process in which environmental enactment is linked to the selection of the environment in which the firm operates.

Finally we found empirical support for out fifth proposition in that variations in terms of internationalization strategies were tightly correlated to variation in the environmental context of reference. In that way, this finding supports the position of Hinings and Greenwood (1988) that the interpretive scheme conditions what the organization does and how it does it. Additionally it is good evidence which points out that cognitive mechanisms as mediating variables within the internationalization strategic process, a topic, as observed by Zahra, Korri and Yu (2005), rarely explored in internationalization studies. 


\section{Theoretical Contributions and Directions for Future Studies}

Considering the empirical evidence in this study, we point out three main theoretical contributions to studies in internationalization strategies and international management. Related to them we indicate some suggestions for future studies.

Firstly, our study contributes evidence that institutional and technical characteristics of the environment, in the way it manifests coercive, normative and mimetic pressures, play a critical role in conditioning internationalization trajectories. In this way, it corroborates the theoretical assumption of the path-dependency theory, specially in the way it has been pointed out by Kogut and Zander (2003a, 2003b). Although in the Brazilian environment, we observed that the reduction of coercive regulatory pressures during the 1990s had a greater influence on internationalization strategies, after the 1990s normative and mimetic pressures started to play a more important role. However, a more focused study should be conducted to identify the clear nature of environmental pressures after the 1990s on the food industry and its influence on internationalization. Yet, considering the role of institutional environmental pressures for legitimacy as argued in the institutional theory and developed in this study, a fertile ground for further research might arise. In that way, taking into account the environmental pressures for institutional legitimacy, it seems possible to understand why some firms conduct certain internationalization strategic choices when there are no evident economic advantages in doing so. That is a critical limitation of economic theories in international business. Our rationale is that internationalization is carried on in order to adequate with environmental pressures for legitimacy. This is the case of some firms which have imported production equipment not due to their need in terms of economic performance improvement, but simply as a form of social legitimacy among their clients.

Secondly, our study contributes to the available theory of internationalization by underpinning the role of financial resources availability and educational qualifications of managers. Additionally, the study points out the need to better understand internationalization strategy within the grown process of the firm. In the same path the study claims for a better understanding of size as a manifestation of resources superiority.

Thirdly, and probably more important, the study touches on the role of cognitive mediation played by interpretive schemes throughout the internationalization process. As observed, the interpretive schemes guide internationalization strategies in two ways. Firstly, they define domains of environmental reference. Secondly, from the environmental context of reference they apprehend values, beliefs and understandings that make internationalization meaningful. The relevance of that is that we could raise a possible understanding as to why some organizations consistently operate in the domestic market when they could benefit from the economic advantages of operating internationally. Although behavioral theories would argue it is because of a lack of experiential knowledge and relational commitment (Johanson \& Vahlne, 1977, 1990, 2006), we argue it is because the interpretive scheme shared among managers of that particular organization is referenced to an environmental context where international action is not important at all or the meanings attached to values do not emphasize internationalization. In this particular study, this was clearly evident among organizations whose interpretive schemes were referenced in the regional environment.

\section{CONCLUSIONS}

In this paper we argued that internationalization is a phenomenon of a strategic nature, processed cognitively by organizational members and susceptible to the influences of the environment and the resources of the organization. 
We analyzed the internationalization strategy carried out within firms of the food industry of Paraná State in Brazil. Within this group we found three main strategic patterns of internationalization: domestic, reluctant and active. Although the patterns identified manifest different levels of international commitment and involvement, we argued that they do not represent stages of internationalization but strategic answers considering the pressures and characteristics of the environment, the resources possessed by organizations, and the cognitive mediation interpretive schemes of organizational members.

We verified that institutional and technical environmental pressures influenced the internationalization strategic pattern of the companies studied. For example we reported the significant reduction of coercive regulation related to international trade within the Brazilian environment during the 1990s. In this way, we noticed that firms founded after 1990 have internationalized faster. This leads us to corroborate our proposition as to the role of the environment in internationalization strategies at the point that international trajectories are to a certain degree dependent on the nature of national institutional environment.

However, we also argued that mainly two factors allow degrees of freedom for the strategic choice process due to environmental pressures for homogenization. One is the role of resources. Our study mainly pointed out the role of the availability of financial resources and the academic qualifications of managers in internationalization. Additionally, size appeared to be an indicator of resource superiority which led us to call for a better understanding of internationalization throughout the growing process of the firms.

Finally, our study shed some light on the cognitive mechanism concerning the strategic choice process on internationalization. Firstly, we observed that organizational members cognitively define domains of reference for action. Secondly, from the environmental context of reference cognitively established, organizational members apprehend values, understandings and meanings that compose their interpretive scheme which guides the internationalization process.

Certainly this study is not without limitations. Firstly, we point out the relatively low number of cases that constituted the sample, as well as the volunteer system sampling used. Therefore the study is non-probabilistic and findings and results can only be applied to the organizations that are in the sample. Furthermore, we have aimed to emphasize the theoretical explanatory rationale that underlies the study rather than its generalization issues. Secondly, considering the data collect instrument used, we understand that it is subject to the understanding of the questions by the respondents and their own bias or preferences which, in some cases, may not represent the opinion of the whole managerial group within the organization. Although we addressed the questionnaires to the CEO of each firm, we had no control over who effectively answered them. Although we took precautions in this respect, we are aware that our description and analysis of both the environmental context description as well as the classification of internationalization strategies might be open to research bias criticism. For example, we know that the internationalization strategies used are substantially broad. In that way stricter classification, as for example the one presented by Jones (1999), would be possible. However, considering our small sample we preferred to use broader categories to analyze internationalization patterns and explanatory possibilities owing to our limitations. The same is true concerning the resources which we argued were critical when it comes to internationalization. They are not unique. As observed, concerns related to the small sample number limited the use of more refined statistical techniques and may have concealed some other resource differences among the firms. We expect future studies to keep control of some variables, size for instance, in order to encompass more homogeneous samples.

\section{REFERENCES}

Aharoni, Y. (1966). The foreign investment decision process. Boston: Harvard Business School. 
Amit, R., \& Schoemaker, P. J. H. (1998). Strategic assets and organizational rent. In S. Segal-Horn (Ed.). The strategy reader. Oxford: Blackwell Publishers.

Associação Brasileira das Indústrias da Alimentação - Abia. (2002). Perspectivas para a indústria da alimentação no Brasil: panorama gráfico-estatístico. São Paulo. Retrieved December 21, 2003, from www.abia.org.br

Axinn, C. N., \& Matthyssens, P. (2001). Reassessing the internationalization of the firm. Oxford: Elsevier.

Axinn, C. N., \& Matthyssens, P. (2002). Viewpoint: limits of internationalization theories in an unlimited world. International Marketing Review, 19(5), 436-449.

Andersson, S. (2000). The internationalization of the firm from an entrepreneurial perspective. International Studies of Management and Organization, 30(1), 63-92.

Andreff, W. (2000). Multinacionais globais. Bauru: EDUSC.

Averbug, A. (1999). Abertura e integração comercial brasileira na década de 90. In F. Giambiagi \& M. M. Moreira (Orgs.). A economia brasileira nos anos 90 (pp. 43-82). Rio de Janeiro: BNDES.

Barney, J. B. (1991). Firm resources and sustained competitive advantage. Journal of Management 17(1), 99-120.

Barney, J. B. (1996). Gaining and sustained competitive advantage. Massachusetts: Addison-Wesley.

Bartunek, J. M. (1984). Changing interpretive schemes and organizational restructuring: the example of a religious order. Administrative Science Quarterly, 29(3), 355-372.

Bell, J., Mcnaughton, R., Young, S., \& Crick, D. (2003). Towards an integrative model of small firm internationalisation. Journal of International Entrepreneurship, 1(4), 339-362.

Banco Nacional de Desenvolvimento Econômico e Social - BNDES (1999, abril). Fusões e aquisições no setor de alimentos. (Informe setorial $n^{0} 15$ ). Rio de Janeiro. RJ, Brasil: Autor.

Buckley, P. J., \& Casson, M. (1976). The future of the multinational enterprise. London: Macmillan, 1976.

Calof, J. L. (1993, October). The impact of size on internationalization. Jornal of Small Business Management, pp. 60-69.

Child, J. (1972). Organizational structure, environment and performance: the role of strategic choice. Sociology, 6(1), 1-22.

Child, J. (1997). Strategic choice in the analysis of action, structure, organizations and environment: retrospect and prospect. Organization Studies, 18(1), 43-76.

Coase, R. H. (1937). The nature of the firm. Economica, 4(16), 386-405.

Cooper, A. C., Gimeno-Gascon, F. J., \& Woo, C. Y. (1994). Initial human and financial capital predictors of new venture performance. Journal of Business Venturing, .9(5), 371-395.

Cyert, R. D., \& March, J. G. (1963). A behavioral theory of the firm. Prentice-Hall: Englewood Cliffs.

Daft, R. L., \& Weick, K. E. (1984). Toward a model of organizations as interpretation systems. Academy of Management Review, 9(2), 284-295. 
DiMaggio, P. J., \& Powell, W. W. (1983). The iron cage revisited: institutional isomorphism and collective rationality in organizational fields. American Sociological Review, 48(2), 147-160.

Dunning, J. H. (1980). Toward an eclectic theory of international production: some empirical tests. Journal of International Business Studies, 11(1), 9-31.

Dunning, J. H. (1988). Explaning international production. London: Harper Collins.

Favaret Filho, P., \& Paula, S., de (2003). A Agroindústria. Retrieved october 28, 2003, from http://www.bndes.gov.br/conhecimento/ livro_setorial/setorial05.pdf

Hannan, M. T, \& Freeman, J. H. (1978). The population ecology of organizations. In M. W. Meyer Environments and organizations (pp. 131-171). San Francisco: Jossey-Bass.

Hennart, J. F. (1982). A theory of multinational enterprise. Ann Arbor: University of Michigan Press.

Hinings, C. R., \& Greenwood, R. (1988). The dynamics of strategic change. Oxford: Basil Blackwell.

Hitt, M. A., Bierman, L., Uhlenbruck, K., \& Shimizu, K. (2006). The importance of resources in the internationalization of professional service firms: the good, the bad, and the ugly. Academy of Management Journal, 49(6), 1137-1157.

Hymer, S. H. (1976). The international operations of national firms. Cambridge, MA: MIT Press.

Johanson. J., \& Vahlne, J. (1977). The internationalization process of the firm: a model of knowledge development and increasing market commitment. Journal of International Business Studies, 8(1), 23-32.

Johanson. J., \& Vahlne, J. (1990). The mechanism of internationalisation. International Marketing Review, 7(4), 11-24.

Johanson. J., \& Vahlne, J. (2006). Commitment and opportunity development in the internationalization process: a note on the uppsala internationalization process model. Management International Review, 46(2), 165-178.

Johnson, G. (1987) Strategic change and the management process. New York : Basil Blackwell.

Jones, M. V. (1999). The internationalization of small high-technology firms. Journal of International Marketing, 7(4), 15-41.

Jones, M. V., \& Coviello, N. E. (2005). Internationalisation: conceptualising an entrepreneurial process of behaviour in time. Journal of International Business Studies, 36(3), 284-303.

Kogut, B., \& Zander, U. (2003a). A memoir and reflection: knowledge and an evolutionary theory of the multinational firm 10 years later. Journal of International Business Studies, 34(6), 505-515.

Kogut, B.. \& Zander, U. (2003b). Knowledge of the firm and the evolutionary theory of the multinational corporation. Journal of International Business Studies, 34(6), 516-529.

Kuhn, T. (1987). A estrutura das revoluções científicas. São Paulo: Perspectiva.

Machado-da-Silva, C. L., \& Barbosa, S. L. de (2002). Estratégia, fatores de competitividade e contexto de referência das organizações: uma análise arquetípica. Revista de Administração Contemporânea, 6(3), 7-32. 
Machado-da-Silva, C. L., \& Fonseca, V. S. da. (1994). Configuração estrutural da indústria calçadista de Novo Hamburgo - RS. Organizações e Sociedade, 2(3), 67-119.

Machado-da-Silva, C. L., \& Fonseca, V. S. da. (1999). Competitividade organizacional: conciliando padrões concorrenciais e padrões institucionais. In M. M. F. Vieira \& L. M. de Barbosa (Orgs.). Administração contemporânea: perspectivas estratégicas (pp. 27-118). São Paulo: Atlas.

Machado-da-Silva, C. L., Fonseca, V. S., \& Fernandes, B. H. R. (2000). Cognição e institucionalização na dinâmica da mudança em organizações. In S. B. Rodrigues \& M. P. Cunha (Orgs.). Estudos organizacionais: novas perspectivas na administração de empresas (pp. 123-150 ). (coletânea luso-brasileira). São Paulo: Iglu.

Machado-da-Silva, C. L., \& Seifert, R. E., Jr. (2004). Ambiente, recursos e interpretação organizacional: um modelo para análise de estratégias de internacionalização. Anais do Encontro de Estudos Organizacionais, Atibaia, SP, Brasil, 3.

Melin, L. (1992). Internationalization as a strategy process. Strategic Management Journal, 13(Special), 99-118.

Meyer, J. W. \& Rowan, B. (1977). Institutionalized organizations: formal structure as myth and ceremony. American Journal of Sociology, 83(2), 340-363.

Oviatt, B. M., \& McDougall, P. P. (1994). Toward a theory of international new ventures. Journal of International Business Studies, 25(1), 45-61.

Oviatt, B. M., \& McDougall, P. P. (1995). Global start-ups: entrepreneurs on a worldwide stage. Academy of Management Executive, 9(2), 30-43.

Parker, B. (1998). Evolução e revolução: da internacionalização à globalização. In S. R. Clegg. C. Hardy, \& W. R. Nord (Eds.). M. Caldas, R. Fachin \& T. Fischer (Orgs.). Handbook de estudos organizacionais (pp. 400-433). São Paulo: Atlas.

Pinheiro, A. C., Giambiagi, F., \& Gostkorzewicz, J. (1999). O desempenho macroeconômico do Brasil nos anos 90. In F. Giambiagi \& M. M. Moreira (Orgs.). A economia brasileira nos anos 90 (pp. 11-41). Rio de Janeiro: BNDES.

Reid, S. D. (1981). The decision-maker and export entry expansion. Journal of International Business Studies, 12(2), 101-112.

Rugman, A. (1980). A new theory of the multinational enterprise: internationalization versus internationalization. Columbia Journal of World Business, 15, pp. 23-29.

Simon, H. (1979). Comportamento administrativo. Rio de Janeiro: FGV.

Tallman, S. (2001). Global strategic management. In M. A. Hitt, R. E. Freeman, \& J. S. Harrison (Eds.). Handbook of strategic management (pp. 464-490). Oxford: Blackwell.

Turnbull, P. W. (1987). A challenge to the stages theory of the internationalization process. In S. D. Reid \& P. J. Rosson (Eds.). Managing export entry and expansion. New York: Praeger.

Vernon, R. (1966). International trade and international investment in the product cycle. Quarterly Journal of Economics, 80, pp. 190-207.

Weick, K. E. (1969). The social psychology of organizing. Reading, MA: Addison-Wesley. 
Welch, L. S., \& Luostarinen, R. (1988). Internationalization: evolution of a concept. Journal of General Management, 14(2), 34-55.

Wernerfelt, B. (1984). A resource-based view of the firm. Strategic Management Journal, 5(2), 171180.

Westhead, P., Wright, M., \& Ucbasaran, D. (2001). The internationalization of new and small firms: a resource based view. Journal of Business Venturing, 16(4), 333-358.

Williamson, O. E. (1975). Markets and hierarchies, analysis and antitrust implications: a study in the economics of internal organization. New York: Free Press.

Zahra, S. A., Korri, J. S., \& Yu, J. (2005). Cognition and international entrepreneurship: implications for research on international opportunity recognition and exploitation. International Business Review, 14(2), 129-146. 


\section{APPENDIX}

\section{Resources Measurement and Non-Parametric Statistical Tests Conducted}

\section{Financial Resources}

\begin{tabular}{|c|c|c|c|c|c|c|c|}
\hline \multirow{2}{*}{\multicolumn{2}{|c|}{ Financial resource indicators }} & \multicolumn{3}{|c|}{ Groups } & \multirow{2}{*}{ Stat Test } & \multirow{2}{*}{$\begin{array}{c}\text { Value } \\
\text { Test }\end{array}$} & \multirow{2}{*}{$\begin{array}{l}\text { Sig. } \\
\text { (p) }\end{array}$} \\
\hline & & Domestic & Reluctant & Active & & & \\
\hline Total sales (millions of R\$) & $\begin{array}{l}\mathrm{n}= \\
\text { mean = } \\
\text { median = } \\
\mathrm{sd}=\end{array}$ & $\begin{array}{c}15 \\
14,83 \\
3 \\
24,80\end{array}$ & $\begin{array}{c}14 \\
26,94 \\
11 \\
41,15\end{array}$ & $\begin{array}{c}17 \\
255,81 \\
59 \\
357,63\end{array}$ & $\begin{array}{l}\text { Kruskal } \\
\text { Wallis }\end{array}$ & $\begin{array}{c}\chi^{2}= \\
12,841\end{array}$ & 0,002 \\
\hline $\begin{array}{l}\text { Production growth in the last } \\
\text { three years }\end{array}$ & $\begin{array}{l}\mathrm{n}= \\
\text { mean = } \\
\text { median = } \\
\mathrm{sd}=\end{array}$ & $\begin{array}{c}15 \\
12,13 \% \\
5 \\
15,97\end{array}$ & $\begin{array}{c}14 \\
55,92 \% \\
22,50 \\
10,4\end{array}$ & $\begin{array}{c}17 \\
19,79 \% \\
11 \\
17,90\end{array}$ & $\begin{array}{l}\text { Kruskal } \\
\text { Wallis }\end{array}$ & $\begin{array}{c}\chi^{2}= \\
3,114\end{array}$ & 0,211 \\
\hline $\begin{array}{l}\text { Need for financial helping (1 } \\
=\text { never; } 7 \text { = always) }\end{array}$ & $\begin{array}{l}\mathrm{n}= \\
\text { mean = } \\
\text { median = } \\
\mathrm{sd}=\end{array}$ & $\begin{array}{c}15 \\
4 \\
5 \\
1,89\end{array}$ & $\begin{array}{c}14 \\
4,71 \\
5 \\
2,05\end{array}$ & $\begin{array}{c}17 \\
4,82 \\
5 \\
1,81\end{array}$ & $\begin{array}{l}\text { Kruskal } \\
\text { Wallis }\end{array}$ & $\begin{array}{c}\chi^{2}= \\
2,589\end{array}$ & 0,274 \\
\hline $\begin{array}{l}\text { Governmental credit for } \\
\text { investment funding }\end{array}$ & $\begin{array}{l}\mathrm{n}= \\
\text { frequency }=\end{array}$ & $\begin{array}{c}17 \\
5,9 \%(1)\end{array}$ & $\begin{array}{c}13 \\
53,8 \%(7)\end{array}$ & $\begin{array}{c}19 \\
68,4 \%(13)\end{array}$ & Pearson & $\begin{array}{c}\chi^{2}= \\
15,201\end{array}$ & 0,001 \\
\hline
\end{tabular}

\section{Physical Resources}

\begin{tabular}{|c|c|c|c|c|c|c|c|}
\hline \multirow{2}{*}{ Physical resource indicators } & & \multicolumn{3}{|c|}{ Groups } & \multirow{2}{*}{$\begin{array}{l}\text { Stat } \\
\text { Test }\end{array}$} & \multirow{2}{*}{$\begin{array}{l}\text { Value } \\
\text { Test }\end{array}$} & \multirow{2}{*}{$\begin{array}{l}\text { Sig. } \\
\text { (p) }\end{array}$} \\
\hline & & Domestic & Reluctant & Active & & & \\
\hline $\begin{array}{l}\text { Production capacity for the } \\
\text { main product ( } Z \text { score) }\end{array}$ & $\begin{array}{l}\mathrm{n}= \\
\text { mean }= \\
\text { median = } \\
\mathrm{sd}=\end{array}$ & $\begin{array}{c}17 \\
-0,40 \\
-0,44 \\
0,09\end{array}$ & $\begin{array}{c}10 \\
-0,31 \\
-0,43 \\
0,30\end{array}$ & $\begin{array}{c}19 \\
0,53 \\
-0,29 \\
1,39\end{array}$ & $\begin{array}{l}\text { Kruskal } \\
\text { Wallis }\end{array}$ & $\begin{array}{c}\chi^{2}= \\
11,362\end{array}$ & 0,003 \\
\hline $\begin{array}{l}\text { Productivity (number of } \\
\text { employees/production } \\
\text { capacity) (Z score) }\end{array}$ & $\begin{array}{l}\mathrm{n}= \\
\text { mean }= \\
\text { median }= \\
\mathrm{sd}=\end{array}$ & $\begin{array}{c}17 \\
0,88 \\
0,86 \\
0,70\end{array}$ & $\begin{array}{c}10 \\
0,74 \\
0,81 \\
0,40\end{array}$ & $\begin{array}{c}19 \\
1,28 \\
0,74 \\
2,73\end{array}$ & $\begin{array}{l}\text { Kruskal } \\
\text { Wallis }\end{array}$ & $\begin{array}{l}\chi^{2}= \\
1,978\end{array}$ & 0,372 \\
\hline $\begin{array}{l}\text { Average age of production } \\
\text { equipment (years) }\end{array}$ & $\begin{array}{l}5-\quad= \\
6-10= \\
11-15= \\
16-20= \\
20+=\end{array}$ & $\begin{array}{c}11,1 \% \\
50 \% \\
16,7 \% \\
22,2 \% \\
-\end{array}$ & $\begin{array}{c}50 \% \\
28,6 \% \\
14,3 \% \\
7,1 \% \\
-\end{array}$ & $\begin{array}{c}15,8 \% \\
57,9 \% \\
10,5 \% \\
10,5 \% \\
5,3 \%\end{array}$ & Pearson & $\begin{array}{c}\chi^{2}= \\
10,830\end{array}$ & 0,212 \\
\hline
\end{tabular}




\section{Human Resources}

\begin{tabular}{|c|c|c|c|c|c|c|c|}
\hline \multirow{2}{*}{\multicolumn{2}{|c|}{ Human resource indicators }} & \multicolumn{3}{|c|}{ Groups } & \multirow{2}{*}{$\begin{array}{l}\text { Stat } \\
\text { Test } \\
\end{array}$} & \multirow{2}{*}{$\begin{array}{c}\text { Value } \\
\text { Test }\end{array}$} & \multirow{2}{*}{$\begin{array}{l}\text { Sig. } \\
\text { (p) }\end{array}$} \\
\hline & & Domestic & Reluctant & Active & & & \\
\hline $\begin{array}{l}\text { Number of managers } \\
\text { responsible for strategic } \\
\text { decision }\end{array}$ & $\begin{array}{l}\mathrm{n}= \\
\text { mean }= \\
\text { median }= \\
\mathrm{sd}=\end{array}$ & $\begin{array}{c}18 \\
3,17 \\
3 \\
1,47\end{array}$ & $\begin{array}{c}14 \\
3,07 \\
3 \\
2,27\end{array}$ & $\begin{array}{c}20 \\
4,20 \\
4 \\
2,24\end{array}$ & $\begin{array}{l}\text { Kruskal } \\
\text { Wallis }\end{array}$ & $\begin{array}{c}\chi^{2}= \\
3,718\end{array}$ & 0,156 \\
\hline $\begin{array}{l}\text { Main executive had } \\
\text { international experience } \\
\text { before joining the firm }\end{array}$ & $\begin{array}{l}\mathrm{n}= \\
\text { frequency = }\end{array}$ & $\begin{array}{c}18 \\
5,6 \%(1)\end{array}$ & $\begin{array}{c}14 \\
28,6 \%(4)\end{array}$ & $\begin{array}{c}20 \\
15 \%(3)\end{array}$ & Pearson & $\begin{array}{c}\chi^{2}= \\
3,208\end{array}$ & 0,201 \\
\hline $\begin{array}{l}\text { Main executive had } \\
\text { foreign language skills } \\
\text { before joining the } \\
\text { company }\end{array}$ & $\begin{array}{l}\mathrm{n}= \\
\text { frequency = }\end{array}$ & $\begin{array}{c}18 \\
22 \%(4)\end{array}$ & $\begin{array}{c}14 \\
57,1 \%(8)\end{array}$ & $\begin{array}{c}20 \\
35 \%(7)\end{array}$ & Pearson & $\begin{array}{c}\chi^{2}= \\
4,175\end{array}$ & 0,124 \\
\hline $\begin{array}{l}\text { Average years of firm } \\
\text { managers' experience in } \\
\text { the food industry }\end{array}$ & $\begin{array}{l}10-= \\
11-20= \\
21-30= \\
30+=\end{array}$ & $\begin{array}{c}27,8 \% \\
33,3 \% \\
33,4 \% \\
5,6 \%\end{array}$ & $\begin{array}{c}42,9 \% \\
35,7 \% \\
21,4 \% \\
-\end{array}$ & $\begin{array}{l}20 \% \\
30 \% \\
40 \% \\
10 \%\end{array}$ & Pearson & $\begin{array}{c}\chi 2= \\
3,890\end{array}$ & 0,692 \\
\hline $\begin{array}{l}\text { Average level of firm } \\
\text { managers' educational } \\
\text { qualification }\end{array}$ & $\begin{array}{l}\text { Elementary } \\
\text { High school } \\
\text { Undergraduate } \\
\text { Postgraduate }\end{array}$ & $\begin{array}{c}5,9 \% \\
35,3 \% \\
41,2 \% \\
17,6 \%\end{array}$ & $\begin{array}{c}7,1 \% \\
- \\
64,3 \% \\
28,6 \%\end{array}$ & $\begin{array}{c}5 \% \\
- \\
55 \% \\
40 \%\end{array}$ & Pearson & $\begin{array}{c}\chi^{2}= \\
14,431\end{array}$ & 0,025 \\
\hline
\end{tabular}

\section{Organizational Resources}

\begin{tabular}{|c|c|c|c|c|c|c|c|}
\hline \multirow{2}{*}{\multicolumn{2}{|c|}{ Organizational resource indicators }} & \multicolumn{3}{|c|}{ Groups } & \multirow{2}{*}{ Stat Test } & \multirow{2}{*}{$\begin{array}{l}\text { Value } \\
\text { Test }\end{array}$} & \multirow{2}{*}{$\begin{array}{l}\text { Sig. } \\
\text { (p) }\end{array}$} \\
\hline & & Domestic & Reluctant & Active & & & \\
\hline Age & $\begin{array}{l}\mathrm{n}= \\
\text { mean }= \\
\text { median = } \\
\mathrm{sd}=\end{array}$ & $\begin{array}{c}17 \\
21,05 \\
16 \\
16,72\end{array}$ & $\begin{array}{c}14 \\
16,28 \\
13,50 \\
12,34\end{array}$ & $\begin{array}{c}19 \\
30,26 \\
36 \\
14,50\end{array}$ & $\begin{array}{l}\text { Kruskal } \\
\text { Walli }\end{array}$ & $\begin{array}{l}\chi^{2}= \\
6,171\end{array}$ & 0,046 \\
\hline $\begin{array}{l}\text { Number of new products } \\
\text { put on the market in the } \\
\text { last three years }\end{array}$ & $\begin{array}{l}\mathrm{n}= \\
\text { mean }= \\
\text { median = } \\
\mathrm{sd}=\end{array}$ & $\begin{array}{c}18 \\
2,33 \\
2 \\
2,72\end{array}$ & $\begin{array}{c}14 \\
2,43 \\
1,50 \\
2,82\end{array}$ & $\begin{array}{c}17 \\
6,47 \\
3 \\
7,62\end{array}$ & $\begin{array}{l}\text { Kruskal } \\
\text { Wallis }\end{array}$ & $\begin{array}{c}\chi^{2}= \\
5,109\end{array}$ & 0,078 \\
\hline $\begin{array}{l}\text { Total sales percentage } \\
\text { used for marketing issues }\end{array}$ & $\begin{array}{l}\mathrm{n}= \\
\text { mean }= \\
\text { median }= \\
\mathrm{sd}=\end{array}$ & $\begin{array}{c}18 \\
1,30 \% \\
1 \% \\
1,54\end{array}$ & $\begin{array}{c}14 \\
1,64 \% \\
1 \% \\
1,44\end{array}$ & $\begin{array}{c}19 \\
2,21 \% \\
1 \% \\
1,58\end{array}$ & $\begin{array}{l}\text { Kruskal } \\
\text { Wallis }\end{array}$ & $\begin{array}{c}\chi^{2}= \\
5,292\end{array}$ & 0,071 \\
\hline $\begin{array}{l}\text { Risk perception }(1=\text { low; } \\
7 \text { = high })\end{array}$ & $\begin{array}{l}\mathrm{n}= \\
\text { mean }= \\
\text { median }= \\
\mathrm{sd}=\end{array}$ & $\begin{array}{c}18 \\
3,44 \\
3,44 \\
1,20\end{array}$ & $\begin{array}{c}14 \\
3,79 \\
4 \\
0,8\end{array}$ & $\begin{array}{c}19 \\
3,95 \\
4 \\
0,97\end{array}$ & $\begin{array}{l}\text { Kruskal } \\
\text { Wallis }\end{array}$ & $\begin{array}{c}\chi^{2}= \\
2,230\end{array}$ & 0,328 \\
\hline $\begin{array}{l}\text { Relationship with } \\
\text { member of the } \\
\text { production chain }(1=\text { far; } \\
7 \text { = close })\end{array}$ & $\begin{array}{l}\mathrm{n}= \\
\text { mean = } \\
\text { median = } \\
\mathrm{sd}=\end{array}$ & $\begin{array}{c}18 \\
4,44 \\
4,50 \\
1,95\end{array}$ & $\begin{array}{c}14 \\
4,64 \\
5 \\
1,82\end{array}$ & $\begin{array}{c}20 \\
5,35 \\
5,50 \\
1,35\end{array}$ & $\begin{array}{l}\text { Kruskal } \\
\text { Wallis }\end{array}$ & $\begin{array}{c}\chi^{2}= \\
2,262\end{array}$ & 0,323 \\
\hline Size & $\begin{array}{l}\text { Small } \\
\text { Medium } \\
\text { Large }\end{array}$ & $\begin{array}{c}77,8 \% \\
16,7 \% \\
5,5 \%\end{array}$ & $\begin{array}{c}78,6 \% \\
21,4 \% \\
-\end{array}$ & $\begin{array}{l}20 \% \\
25 \% \\
55 \%\end{array}$ & Pearson & $\begin{array}{c}\chi 2= \\
22,226\end{array}$ & 0,000 \\
\hline
\end{tabular}

